\title{
MEMAHAMI METODE ANALISIS PASANGAN BIBLIOGRAFI (BIBLIOGRAPHIC COUPLING) DAN KO-SITASI (CO-CITATION) SERTA MANFAATNYA UNTUK PENELITIAN KEPUSTAKAAN
}

\author{
I Komang Rupadha ${ }^{\text {*) }}$ \\ UPT Perpustakaan Universitas Mataram \\ Jalan Majapahit No. 62, Kec. Mataram, Nusa Tenggara Barat 83121 \\ ${ }^{*)}$ Korespondensi: k_rupadha@yahoo.com
}

\begin{abstract}
[Title: Understanding Bibliographic Coupling and Co-Citation Method and it Benefits for References Research JThis paper aims to provide a general description and as a conductor to understand more about the analysis and copartner bibliographic citation, as one of the techniques of research in librarianship, especially to identify the relationship between a document with other documents based on proximity or closeness of the subject. The discussion in this paper will focus on some basic aspects that include the definition, data collection procedures, and data analysis, and benefit analysis of bibliographic partner and co-citation. To provide a more real, at the end of the example given research technique that uses analysis and co-partner bibliographic citation. The results of this study show that: 1) The study analyzes the pair co-citation bibliography and useful to determine the level of conformity between the subject of some of the documents cited by citing documents. The higher the frequency / power of bibliographic partner and co-citation, then the closer conformity / similarity of the subject of several documents that cite the same document. 2) In relation to the process of indexing and information search, the pair analysis bibliography (bibliographic coupling) and co-citation is very useful for the preparation of the citation index. 3) Honeymooners bibliography and co-citation can be used to map the documents based on the size of the proximity of one document to another document.
\end{abstract}

Keyword: bibliography; bibliographic pair analysis; co-citation.

\begin{abstract}
Abstrak
Makalah ini bertujuan untuk memberikan gambaran secara umum dan sebagai penghantar untuk memahami lebih lanjut mengenai analisis pasangan bibliografi dan ko-sitasi, sebagai salah satu teknikpenelitian bidang kepustakawanan, khususnya untuk mengidentifikasi hubungan antara satu dokumen dengan dokumen lainnya berdasarkan kedekatan atau keeratan subyeknya. Pembahasan dalam makalah ini akan difokuskan pada beberapa aspek dasar yang meliputi pengertian, prosedur pengumpulan data, dan analisis data, dan manfaat analisis pasangan bibliografi dan ko-sitasi. Hasil kajian ini menunjukkan bahwa : 1) Analisis pasangan bibliografi dan ko-sitasi bermanfaat untuk mengetahui tingkat kesesuaian subyek diantara beberapa dokumen yang disitir dengan dokumen yang menyitir. Semakin tinggi frekuensi/kekuatan pasangan bibliografi dan ko-sitasinya, maka semakin dekat pula kesesuaian/kesamaan subyek beberapa dokumen yang menyitir dokumen yang sama. 2) Dalam hubungannya dengan proses pengindeksan dan penelusuran informasi, maka analisis pasangan bibliografi (bibliographic coupling) dan ko-sitasi (co-citation) sangat bermanfaat untuk pembuatan indeks sitasi. 3) Pasangan bibliografi dan ko-sitasi dapat digunakan untuk memetakan dokumen-dokumen berdasarkan ukuran kedekatan satu dokumen dengan dokumen lain.
\end{abstract}

Kata kunci: bibliografi; analisis pasangan bibliograf; ko-sitasi.

\section{A. PENGANTAR}

Sebagaimana diketahui bahwa analisis pasangan bibliografi dan ko-sitasi merupakan suatu metode atau teknik analisis dalam penelitian di bidang ilmu perpustakaan, khususnya yang memfokuskan 
kajiannya untuk mengidentifikasi hubungan kedekatan atau keeratan subyek antara satu dokumen dengan dokumen lainnya. Penulis sengaja memilih topik pembahasan mengenai analisis pasangan bibliografi dan ko-sitasi ini, sebagai salah satu sumbangan untuk menambah wawasan bagi para pejabat fungsional pustakawan yang menekuni profesinya sebagai pelayan informasi, dalam pengembangan kariernya. Sebab berdasarkan pengalaman penulis selama menjabat sebagai pustakawan, bahwa salah satu kegiatan yang paling berat adalah kegaiatan penelitian di bidang kepustakawanan itu sendiri. Sehingga bagi pustakawan kegiatan penelitian yang merupakan salah satu butir kegiatan wajib, sangat jarang dan bahkan hampir tidak pernah dilakukan. Akibatnya pengembangan kariernya sedikit terhambat, hanya karena minimnya pemahaman tentang metode atau teknik penelitian yang dimiliki oleh yang bersangkutan. Berdasarkan pemikiran itu, penulis mencoba memberikan secuil sumbangan untuk mengatasi masalah di atas, walaupun sedikit klasik, namun penulis berharap ada manfaatnya.

Sebagaimana dijelaskan di atas, bahwa pembahasan dalam makalah ini dimaksudkan untuk memberikan gambaran secara umum dan sebagai penghantar untuk memahami lebih lanjut mengenai analisis pasangan bibliografi dan ko-sitasi, sebagai salah satu teknik penelitian bidang kepustakawanan, khususnya untuk mengidentifikasi hubungan antara satu dokumen dengan dokumen lainnya berdasarkan kedekatan atau keeratan subyeknya. Pembahasan akan difokuskan pada beberapa aspek dasar yang meliputi pengertian, prosedur pengumpulan data, dan analisis data, dan manfaat analisis pasangan bibliografi dan ko-sitasi. Untuk memberikan gambaran yang lebih riil, pada bagian akhir diberikan contoh teknik penelitian yang menggunakan analisis pasangan bibliografi dan ko-sitasi.

\section{B. PENGERTIAN}

\section{Pasangan Bibliografi (bibliographic coupling)}

Menurut Kessler (1963), pasangan bibliografi adalah satu dokumen yang disitir secara bersama-sama oleh dua dokumen/karya yang diterbitkan kemudian. Dari definisi tersebut maka jika 2 (dua) dokumen menyitir paling sedikit satu dokumen yang sama dikatakan bahwa kedua dokumen tersebut terkapling secara bibliografi. Secara praktis hal ini dapat dilihat pada daftar referensi yang terdapat dalam kedua dokumen. Apabila pada kedua dokumen tersebut terdapat paling sedikit satu referensi yang sama maka dikatakan bahwa kedua dokumen tersebut terkapling secara bibliografi. Adapun dokumen yang tercantum secara bersama-sama dalam daftar referensi kedua dokumen tersebut dinamakan pasangan bibliografi.

Banyaknya dokumen yang disitir secara bersama-sama oleh dua dokumen yang terbit kemudian disebut frekuensi pasangan bibliografi atau kekuatan pasangan (coupling strength). Semakin banyak jumlah dokumen yang disitir secara bersama-sama oleh dua dokumen atau semakin besar frekuensi pasangan bibliografi maka semakin tinggi kekuatan pasangan kedua dokumen tersebut. 


\section{Ko-Sitasi (Co-Citation)}

Ko-sitasi adalah 2 (dua) dokumen yang disitir secara bersama-sama oleh paling sediikit satu dokumen yang terbit kemudian. Dengan kata lain jika 2 (dua) dokumen disitir secara bersama-sama oleh paling sedikit satu dokumen maka dikatakan bahwa kedua dokumen tersebut disebut ko-sitasi. Secara praktis suatu pasangan yang terdiri dari dokumen dikatakan ko-sitasi apabila dapat ditemukan paling sedikit satu dokumen yang menyitir pasangan dokumen tersebut secara bersama-sama.

Banyaknya dokumen yang menyitir 2 (dua) dokumen sebelumnya secara bersama-sama disebut frrekuensi atau kekuatan ko-sitasi. Dua dokumen mempunyai kekuatan ko-sitasi yang tinggi apabila semakin banyak dokumen yang terbit kemudian yang menyitir kedua dokumen tersebut. Oleh karena itu, pola ko-sitasi berubah dari waktu ke waktu.

Untuk memperjelas pengertian pasangan bibliografi dan ko-sitasi diberikan ilustrasi pada Gambar 1.

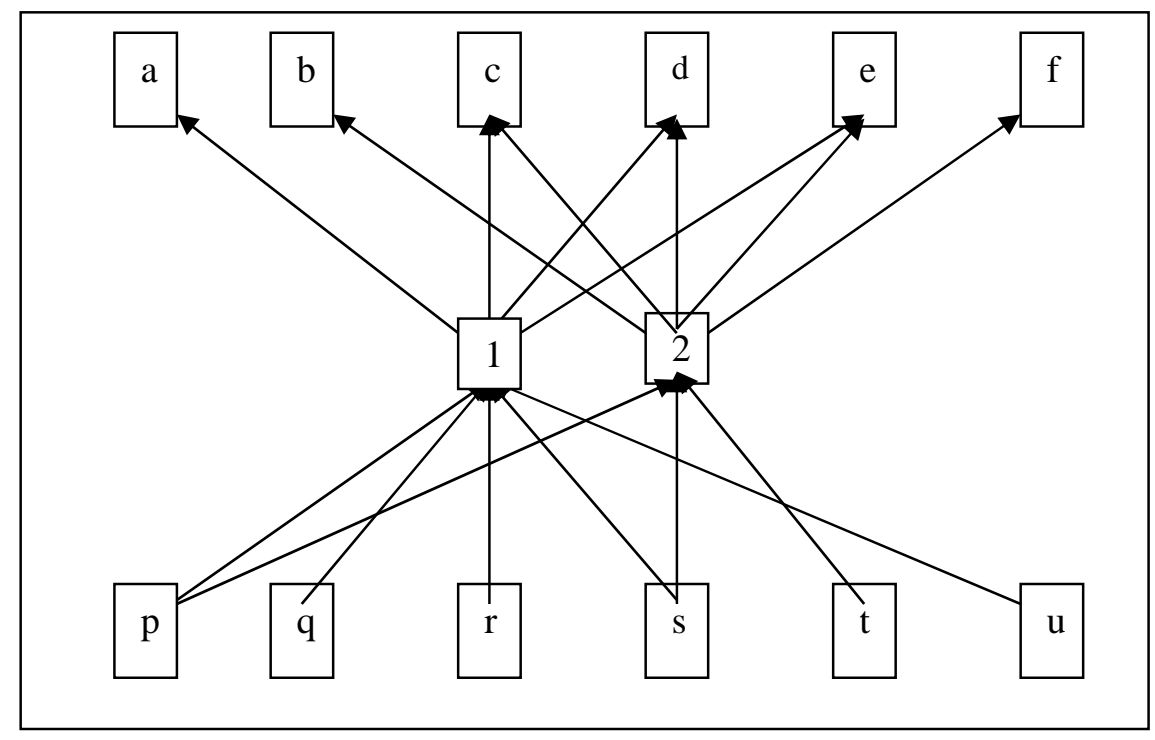

Gambar 1. Pasangan bibliografi dan ko-sitasi

Dokumen 1 dan dokumen 2 merupakan pasangan dokumen yang menjadi objek pengamatan. Dokumen 1 mempunyai referensi yaitu dokumen: $\boldsymbol{a}, \boldsymbol{c}, \boldsymbol{d}$ dan $\boldsymbol{e}$, sedang dokumen 2juga mempunyai referensi yaitu dokumen: $\boldsymbol{b}, \boldsymbol{c}, \boldsymbol{d}, \boldsymbol{e}$, dan $\boldsymbol{f}$. Kalau diperhatikan dari referensi yang dimiliki oleh dokumen 1 dan dokumen 2 , maka terlihat ada 3 referensi yang sama, yaitu : $\boldsymbol{c}, \boldsymbol{d}$, dan $\boldsymbol{e}$. Oleh karena itu dikatakan bahwa $\boldsymbol{c}, \boldsymbol{d}$, dan $\boldsymbol{e}$ merupakan pasangan bibliografi. Dokumen 1 dan dokumen 2 dikatakan terkapling secara bibliografi. Adapun kekuatan pasangan antara dokumen 1 dan dokumen 2 adalah 3, karena hanya ada 3 dokumen saja yang disitir secara bersama-sama oleh pasangan dokumen tersebut yaitu dokumen $\boldsymbol{c}, \boldsymbol{d}$, dan $\boldsymbol{e}$.

Selanjutnya dokumen 1 disitir oleh dokumen $\boldsymbol{p}, \boldsymbol{q}, \boldsymbol{r}$, $\boldsymbol{s}$, dan $\boldsymbol{u}$; sedang dokumen 2 disitir oleh dokumen $\boldsymbol{p}$, $\boldsymbol{s}$, dan $\boldsymbol{t}$.Dari sitiran tersebut terlihat bahwa dokumen 1 dan dokumen 2 disitir secara 
bersama-sama oleh dokumen $\boldsymbol{p}$ dan $\boldsymbol{s}$. Oleh karena itu dikatakan bahwa dokumen 1 dan dokumen 2 merupakan ko-sitasi. Adapun kekuatan ko-sitasinya adalah 2, karena hanya ada 2 dokumen saja yang menyitir secara bersama-sama kedua dokumen tersebut, yaitu dokumen $\boldsymbol{p}$ dan $\boldsymbol{s}$.

\section{ANALISIS HUBUNGAN PASANGAN BIBLIOBRAFI DAN KO-SITASI DENGAN SUBYEK DOKUMEN}

Sebagaimana telah dikemukakan bahwa dokumen merupakan media untuk menyampaikan informasi dari penulis/pengarang kepada pembaca. Informasi yang terkandung dalam suatu dokumen mempunyai tema (sebjek) tertentu. Kandungan informasi dokumen biasanya dinyatakan dalam suatu bentuk representasi yang berfungsi sebagai pintu gerbang untuk memasuki subjek dokumen. Bentuk representasi yang lazim dipergunakan adalah kode klasifikasi dan indeks.

Apabila 2 (dua) dokumen berisi informasi yang berada dalam subjek yang sama maka dokumen tersebut mempunyai kode klasifikasi atau indeks yang sama. Beberapa dokumen yang menyitir dokumen yang sama (mempunyai referensi yang sama) memberikan indikasi adanya hubungan tertentu di antara dokumen-dokumen tersebut. Oleh karena itu, adanya pasangan bibliografi memberikan indikasi adanya hubungan tertentu di antara dokumen-dokumen yang bersangkutan. Hubungan tersebut mengarah pada hubungan subjek (Vladutz, G.\& J.Cook, 1984). Demikian halnya seperti yang dikemukakan oleh Kessler (1965) yang menyatakan bahwa ada hubungan yang erat $(\mathrm{r}=0,9)$ antara pasangan bibliografi dengan indeks subjek.

Sebaliknya, beberapa dokumen yang secara bersama-sama disitir oleh suatu dokumen juga memberikan indikasi adanya hubungan tertentu. Hal ini menunjukkan bahwa adanya ko-sitasi juga memberikan indikasi hubungan tertentu di antara dokumen-dokumen tersebut. Hubungan tersebut dimaksudkan juga lebih mengarah pada hubungan subjek seperti yang dikemukakan oleh McCain (1991), dan Small (1973, 1980, 1987).

Adanya hubungan yang erat antara pasangan bibliografi dengan subjek maka apabila 2 (dua) dokumen mempunyai pasangan bibliografi dengan kekuatan yang besar maka kedua dokumen tersebut mempunyai peluang yang besar untuk disitir oleh dokumen yang diterbit pada periode waktu berikutnya. Oleh karena itu, kedua dokumen tersebut mempunyai peluang yang besar untuk mendapatkan ko-sitasi. Hal ini telah dibuktikan oleh Hasibuan (1995) yang menyatakan bahwa semakin tinggi frekuensi/kekuatan pasangan bibliografi maka semakin tinggi frekuensi ko-sitasi.

Dari uraian di atas dapat diringkaskan bahwa hubungan antara paangan bibliografi, ko-sitasi, dan subjek dokumen adalah sebagai berikut:

1. Semakin tinggi frekuensi/kekuatan pasangan bibliografi semakin dekat hubungan subjek di antara kedua dokumen. 
2. Semakin tinggi frekuensi ko-sitasi semakin dekat hubungan subjek di antara kedua dokumen.

3. Semakin tinggi frekuensi/kekuatan pasangan bibliografi semakin tinggi frekuensi kositasi.

Hubungan tersebut dapat diilustrasikan dengan Gambar 2 di bawah ini:

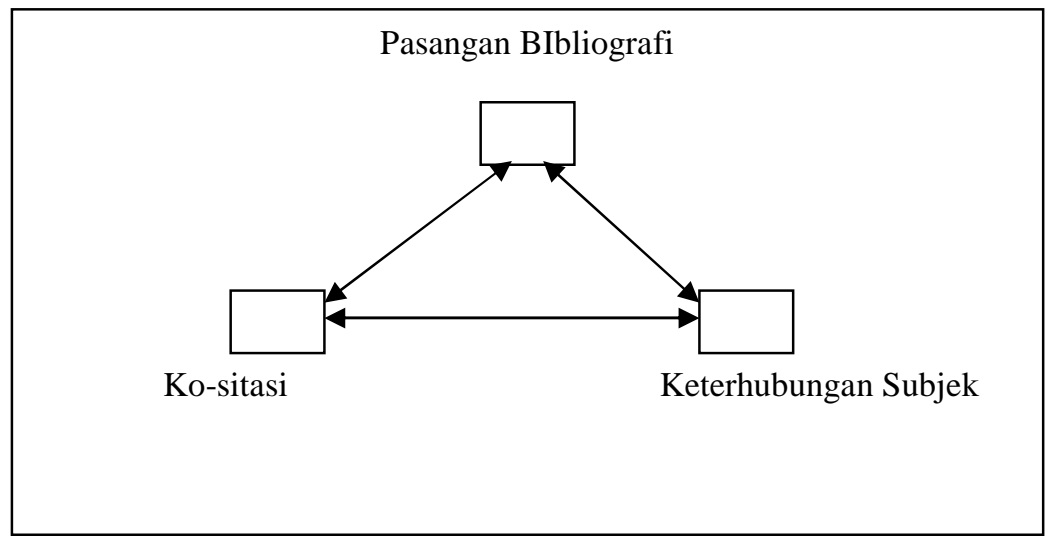

Gambar 2. Hubungan antara pasangan bibliografi, ko-sitasi, dan subjek dokumen

Untuk melihat hubungan antara pasangan bibliografi, ko-sitasi, dan keterhubungan subjek dalam suatu koleksi dokumen diperlukan analisis terhadap subjek dokumen. Dalam hal ini analisis terhadap subjek dokumen meliputi penentuan subjek masing-masing dokumen dan ukuran kedekatan subjek di antara dua dokumen. Subjek dokumen dapat dinyatakan dengan notasi klasifikasi atau indeks. Indeks dapat berupa kata atau istilah dalam bahasa alamiah (natural language), yaitu bahasa yang digunakan dalam dokumen, atau istilah dalam kosa kata terkendali (controlled vocabulary) seperti thesaurus. Indeks yang disusun dengan menggunakan kosa kata terkendali disebut deskriptor. Adapun variabel yang dapat digunakan sebgai ukuran kedekatan subjek antara lain notasi klasifikasi yang digunakan secara bersama oleh dua dokumen, deskriptor yang digunakan secara bersama oleh dua dokumen (co-descriptor), atau kata kunci yang digunakan secara bersama oleh dua dokumen (coword).

Ada 2 (dua) tipe analisis statistik yang dapat digunakan untuk memeriksa hubungan antar variabel, yaitu:

a. Analisis yang bertujuan untuk mengidentifikasi adanya hubungan antar variabel, antara lain $x^{2}$ (chi square)

b. Analisis yang bertujuan untuk mengukur keeratan hubungan antar variabel, antara lain analisis korelasi $(p)$.

Di samping itu ada beberapa analisis statistik yang dapat digunakan untuk menguji berbagai karakteristik yang berkaitan dengan satu atau beberapa variabel antara lain: 
a. Analisis yang bertujuan untuk menguji nilai tengah, antara lain uji t dan uji Z.

b. Analisis yang bertujuan untuk menguji keragaman (variance), antara lain uji F.

c. Analisis yang bertujuan untuk mengelompokkan objek berdasarkan kesamaan (similarity) antara satu ojek dengan objek lain, antara lin analisis gerombol (cluster analysis).

Seperti halnya pada analisis statistik deskriptif, analisis statistik inferensia ini dapat dilakukan dengan menggunakan paket program statistik.

\section{MANFAAT ANALISIS PASANGAN BIBLIOGRAFI (BIBLIOGRAPHIC COUPLING) DAN KO-SITASI (CO-CITATION).}

Analisis pasangan bibliografi dan ko-sitasi memberikan beberapa manfaat dalam ilmu informasi baik secara teoritis mupun secara praktis, antara lain:

1. pengindeksan,

2. penelusuran informasi, dan

3. pemetaan sains dan teknologi.

\section{Pengindeksan}

Pengindeksan yang bertujuan untuk mempresentasikan informasi yang terkandung dalam dokumen biasanya didasarkan karakteristik dokumen itu sendiri. Menurut Harter, S.P., (1993), adanya fenomena pasangan bibliografi dan kositasi, memberikan indikasi adanya keterhubungan antara suatu dokumen dengan dokumen disitir (citie document) atau referensi, dan antara suatu dokumen dengan dokumen yang menyitir (citing document) atau sitasi memberikan alternatif lain dalam proses pengindeksan, yaitu pengindeksan sitasi (citation indexing).

Dalam pengindeksan sitasi suatu dokumen dipresentasikan dengan dokumen lain, yaitu dokumen yang disitir (referensi) dan dokumen yang menyitir (sitasi). Menurut Garfield (1979) pengindeksan sitasi mempunyai 3 (tiga) manfaat dengan karakteristik yang khas, yaitu:

a. Memberikan kategorisasi dokumen secara tepat dan terperinci;

b. Dapat mengungkapkan secara eksplisit adanya keterhubungan intelektual antara literatur yang lama dengan literatur yang baru;

c. Dapat mengungkapkan secara eksplisit hubungan di antara kejadian-kejadian yang lama dengan kejadia-kejadian yang baru yang membangun terbentuknya disiplin atau spesialisasi.

\section{Penelusuran informasi}

Indeks merupakan titik akses menghubungkan dokumen dengan pencari informasi. Metode penelusuran yang populer adalah penelusuran dengan menggunakan deskriptor atau kata kunci. Akan tetapi dengan disediakannya indeks sitasi memungkinkan penelusuran dilakukan dengan menggunakan sitasi (citation searching). Menurut Chapman, J. (1981), penelusuran berdasarkan sitasi 
merupakan upaya yang logis untuk menemukan dokumen yang relevan karena adanya keterhubungan subjek antara sutau dokumen dengan dokumen yang disitir (citied document) dan antara suatu dokumen dengan dokumen yang menyitir (citing document). Oleh karena itu, untuk meningkatkan efektivitas penelusuran beberapa peneliti seperti yang dikemukakan oleh Griffiths, A., Luckhurst, H.C. \& Willett, P. (1986), bahwa dalam menggunakan sistem penelusuran dokumen, merekomendasikan untuk menggabungkan sistem penelusuran berdasarkan deskriptor dan penelusuran berdasarkan sitasi.

\section{Pemetaan}

Bonzi,S.(1982), menyatakan bahwa pasangan bibliografi dan ko-sitasi merupakan karakteristik dokumen yang didasarkan pada atribut yang dimiliki oleh dokumen yang disitir (referensi) dan dokumen yang menyitir (sitasi). Seperti halnya karakteristik yang didasarkan pada atribut dokumen secara langsung (seperti pengarang, kata kunci, afiliasi pengarang, nama jurnal, tempat publikasi, dan lain-lain), pasangan bibilografi dan ko-sitasi dapat juga digunakan untuk mengukur hubungan antara satu dokumen dengan dokumen lain. Dalam kaitannya dengan pemetaan ilmu pengetahuan, Braam, R.R., Moed H., dan Van Raan, A.F.J. (1991), menyatakan bahwa, pasangan bibliografi dan ko-sitasi dapat digunakan untuk memetakan dokumen-dokumen berdasarkan ukuran kedekatan subjek satu dokumen dengan dokumen lain.

\section{E. PROSEDUR PENGUMPULAN DATA DALAM ANALISIS}

Untuk melakukan analisis pasangan bibliografi dan ko-sitasi, terlebih dahulu kita perlu mengumpulkan data. Adapun prosedur pengumpulan data untuk masing-masing kegiatan analisis tersebut adalah sebagai berikut:

\section{Pasangan Bibliografi (Bibliographic Coupling)}

Prosedur pengumpulan data pasangan bibliografi adalah sebagai berikut :

a) Menentukan koleksi uji, yaitu koleksi dokumen dalam suatu subjek atau topik tertentu yang akan diamati.

b) Mengumpulkan data bibliografi dokumen yang disitr, yaitu data bibliografi dokumen yang terdapat dalam daftar pustaka (referensi).

c) Memasangkan setiap dokumen dalam koleksi uji satu sama lain.

d) Memeriksa data bibliografi dokumen yang disitir pada setiap pasangan dokumen.

e) Menghitung banyaknya dokumen yang disitir secara bersama-sama oleh pasangan dokumen.

\section{Ko-Sitasi (Co-Citation)}

Prosedur pengumpulan data ko-sitasi adalah sebagai berikut :

a) Menentukan koleksi uji yaitu koleksi dokumen dalam suatu subjek atau topik tertentu yang akan diamati. 
b) Mengumpulkan dokumen yang menyitir, yaitu dokumen yang terbit pada periode waktu berikutnya yang menggunakan dokumen dalam koleksi uji sebagai referensinya.

c) Memasangkan setiap dokumen dalam koleksi uji satu sama lain.

d) Memeriksa daftar pustaka atau referensi pada dokumen yang menyitir.

e) Menghitung banyaknya dokumen yang menyitir secara bersama-sama setiap pasangan dokumen dalam koleksi uji.

Ko-sitasi dapat berubah dengan bertambahnya waktu, karena banyaknya dokumen yang menyitir suatu pasangan dokumen dapat bertambah apabila waktunya bertambah. Oleh karena itu dalam analisis ko-sitasi harus diberikan batasan periode waktu pengamatan. Periode waktu ini ditentukan berdasarkan pertimbangan untuk memberikan waktu yang cukup bagi koleksi uji untuk disitir.

\section{Beberapa Kendala dalam Pengumpulan Data}

Pengumpulan data mengenai pasangan bibliografi dan ko-sitasi berkaitan dengan penelusuran dokumen pada suatu subjek tertentu. Pengumpulan data dapat dilakukan dengan penelusuran secara manual untuk mendapatkan dokumen secara fisik, atau penelusuran secara otomatis dengan menggunakan basis data untuk mendapatkan data bibliografi dokumen. Pengumpulan data secara manual mempunyai beberapa kendala, antara lain:

1. Koleksi dokumen dalam suatu subjek tertentu seringkali tidak lengkap.

2. Keberadaan dokumen yang "terserak" di berbagai tempat.

3. Pencantuman data dalam daftar pustaka seringkali tidak lengkap.

4. Cara penulisan daftar pustaka bervariasi.

5. Memerlukan sumber daya (waktu, tenaga, dan biaya) yang sangat besar. Adapun kendala yang dihadapi dalam pengumpulan data secara otomatis antara lain:

1. Keterbatasan cakupan basis data bibliografi dalam suatu subjek tertentu.

2. Keterbatasan cakupan basis data sitasi dalam suatu subjek tertentu, misalnya social science citation index (ssci).

3. Permasalahan teknis yang muncul dalam data mining dari basis data. Hal ini disebabkan antara lain oleh adanya kesalahan/variasi ejaan dan penggunaan format yang tidak standard, yang biasanya terjadinya dalam penulisan judul jurnal, singkatan judul jurnal, tahun, volume, nomor, dan lain-lain. 


\section{F. PROSEDUR ANALISIS DATA}

\section{Analisis Deskriptif}

Analisis deskriptif dimaksudkan untuk mendiskriptifkan data secara ringkas dan jelas agar dapat memberikan informasi yang berguna. Analisis ini diawali dengan penyajian data, kemudian diikuti dengan perhitungan dan analisis statistic deskriptif.

\section{a) Penyajian data}

Data dapat disajikan dalam bentuk tabel atau grafik. Jenis tabel yang popular dan banyak digunakan adlah tabel senarai, tabel distribusi trekuensi, dan tabulasi silang. Tabel senarai memperlihatkan senarai antara objek-objek yang diamati (unit pengamatan) dengan nilai variabel, tabel distribusi frekuensi memperlihatkan hubungan antara nilai atau kategori nilai variabel banyaknya objek, dan tabulasi silang memperlihatkan distribusi objek apabila dilihat dari dua atau lebih variabel atau karakteristiknya. Adapun jenis grafik yang populer dan banyak digunakan adalah histogram, grafik poligon frekuensi, grafik frekuensi kumulatif, dan grafik lingkaran.

Sebagai contoh diberikan data pasangan bibliografi dan ko-sitasi secara hipotetik dari 6 dokumen yang menjadi koleksi uji dalam suatu subjek tertentu. Data tersebut disajikan dalam tabel senarai seperti pada Tabel 1.

\section{Tabel 1}

Kekuatan pasangan bibliografi dan kekuatan ko-sitasi pada pasangan dokumen dalam koleksi uji

\begin{tabular}{|r|c|c|c|}
\hline No. & $\begin{array}{c}\text { Pasangan } \\
\text { dokumen }\end{array}$ & $\begin{array}{c}\text { Kekuatan } \\
\text { Pasangan } \\
\text { bibliografi }\end{array}$ & $\begin{array}{c}\text { Kekuatan } \\
\text { Ko-sitasi }\end{array}$ \\
\hline 1. & $(001: 002)$ & 1 & 0 \\
\hline 2. & $(001: 003)$ & 5 & 1 \\
\hline 3. & $(001: 004)$ & 0 & 0 \\
\hline 4. & $(001: 005)$ & 2 & 0 \\
\hline 5. & $(001: 006)$ & 0 & 0 \\
\hline 6. & $(002: 003)$ & 8 & 2 \\
\hline 7. & $(002: 004)$ & 0 & 3 \\
\hline 8. & $(002: 005)$ & 3 & 0 \\
\hline 9. & $(002: 006)$ & 2 & 0 \\
\hline 10. & $(003: 004)$ & 0 & 2 \\
\hline 11. & $(003: 005)$ & 0 & 0 \\
\hline 12. & $(003: 006)$ & 1 & 0 \\
\hline 13. & $(004: 005)$ & 5 & 4 \\
\hline 14. & $(004: 006)$ & 0 & 0 \\
\hline 15. & $(005: 006)$ & 2 & 0 \\
\hline & Jumlah & 29 & 12 \\
\hline
\end{tabular}


Dari data hipotetik di atas dapat disajikan tabel distribusi frekuensi pasangan dokumen berdasarkan kekuatan pasangan bibliografi seperti pada Tabel 2, dan berdasarkan kekuatan kositasi seperti pada Tabel 3 .

Tabel 2

Distribusi frekuensi pasangan dokumen berdasarkan kekuatan pasangan bibliografi

\begin{tabular}{|c|c|c|}
\hline \multirow{2}{*}{$\begin{array}{c}\text { Kekuatan } \\
\text { pasangan } \\
\text { bibliografi }\end{array}$} & \multicolumn{2}{|c|}{ Pasangan dokumen } \\
\cline { 2 - 3 } & Frekuensi & Persentase \\
\hline 0 & 6 & 40,00 \\
\hline 1 & 2 & 13,33 \\
\hline 2 & 3 & 20,00 \\
\hline 3 & 1 & 6,67 \\
\hline 4 & 0 & 0,00 \\
\hline 5 & 2 & 13,33 \\
\hline 6 & 0 & 0,00 \\
\hline 7 & 0 & 0,00 \\
\hline 8 & 1 & 6,67 \\
\hline Jumlah & 15 & 100 \\
\hline
\end{tabular}

Tabel 3

Distribusi frekuensi pasangan dokumen berdasarkan kekuatan ko-sitasi

\begin{tabular}{|c|c|c|}
\hline \multirow{2}{*}{$\begin{array}{c}\text { Kekuatan } \\
\text { pasangan bibliografi }\end{array}$} & \multicolumn{2}{|c|}{ Pasangan dokumen } \\
\cline { 2 - 3 } & Frekuensi & Persentase \\
\hline 0 & 10 & 66,67 \\
\hline 1 & 1 & 6,67 \\
\hline 2 & 2 & 13,34 \\
\hline 3 & 1 & 6,67 \\
\hline 4 & 1 & 6,67 \\
\hline Jumlah & 15 & 100 \\
\hline
\end{tabular}

Selain itu, dari data hipotetik di atas dapat disajikan tabulasi silang yang menunjukkan distribusi pasangan dokumen apabila dilihat dari kekuatan pasangan bibliografi dan kekuatan kositasi seperti pada Tabel 4.

Tabel 4.

Banyaknya pasangan dokumen berdasarkan kekuatan pasangan bibliografi dan kekuatan ko-sitasi

\begin{tabular}{|c|c|c|c|c|}
\hline \multirow{2}{*}{$\begin{array}{c}\text { Kekuatan pasangan } \\
\text { bibliografi }\end{array}$} & \multicolumn{3}{|c|}{ Kekuatan ko-sitasi } & Jumlah \\
\cline { 2 - 5 } & $0-1$ & $2-3$ & $4-5$ & \\
\hline $0-2$ & 9 & 2 & 0 & 11 \\
\hline $3-5$ & 2 & 0 & 1 & 3 \\
\hline $6-8$ & 0 & 1 & 0 & 1 \\
\hline Jumlah & 11 & 3 & 1 & 15 \\
\hline
\end{tabular}




\section{b) Perhitungan dan analisis statistic deskriptif}

Statistik dekriptif yang mencakup ukuran pemusatan seperti median, modus, nilai tengan (mean), dan kuantil serta ukuran pemencaran seperti kisaran, jarak antar kuartil, simpangan dari nilai tengah, dan ragam dapat digunakan untuk menggali dan mengungkap informasi yang penting dari fenomena pasangan bibliografi dan ko-sitasi. Perhitungan statistik deskriptif ini dapat dilakukan secara manual atau menggunakan program paket statistik seperti Microstat, Kwikstat, SPSS, dan lain-lain.

\section{G. SIMPULAN}

Dari beberapa uraian di atas dapat disimpulkan bahwa :

1. Kajian analisis pasangan bibliografi dan ko-sitasi bermanfaat untuk mengetahui tingkat kesesuaian subyek di antara beberapa dokumen yang disitir dengan dokumen yang menyitir. Semakin tinggi frekuensi/kekuatan pasangan bibliografi danko-sitasinya, maka semakin dekat pula kesesuaian/kesamaan subyek beberapa dokumen yang menyitir dokumen yang sama.

2. Dalam hubungannya dengan proses pengindeksan dan penelusuran informasi, maka analisis pasangan bibliografi (bibliographic coupling) dan ko-sitasi (co-citation) sangat bermanfaat untuk pembuatan indeks sitasi. Menurut Garfield (1979) pengindeksan sitasi mempunyai 3 (tiga) karakteristik yang khas, yaitu:

a. Memberikan kategorisasi dokumen secara tepat dan terperinci;

b. Dapat mengungkapkan secara eksplisit adanya keterhubungan intelektual antara literatur yang lama dengan literatur yang baru;

c. Dapat mengungkapkan secara eksplisit hubungan di antara kejadian-kejadian yang lama dengan kejadia-kejadian yang baru yang membangun terbentuknya disiplin atau spesialisasi.

3. Pasangan bibliografi dan ko-sitasi dapat digunakan untuk memetakan dokumen-dokumen berdasarkan ukuran kedekatan satu dokumen dengan dokumen lain.

\section{DAFTAR PUSTAKA}

Bonzi, Susan (1982). Characteristic of a literature as predictors of relatedness between cited and citing works, Journal of the American Society for Information Science, Vol. 33 (4), 208-216.

Braam, R.R., Moed H. \& Van Raan, A.F.J. (1991), Mapping of Science by combined co-citation and word analysis : I Structural aspects. Journal of the American Society for Information Science, Vol. 42 (4), 233-251. 
Braam, R.R., Moed H. \& Van Raan, A.F.J. (1991), Mapping of Science by combined co-citation and word analysis : II Dynamical aspects. Journal of the American Society for Information Science, Vol. 42 (4), 252-266.

Chapman, J. and K. Subramanyam. (1981), Citation search strategy. National Online Meeting, 97-102.

Grafield, E. (1979), Citation Indexing: Its theory and application in Science, Technology and Humanities, New York; John Wiley \& Sons.

Griffiths, A, Luckhurst, H.C., \& Willett, P. (1986). Using inter-document similarity information in document retrival system.Journal of the American Society for Information Science, Vol. 37 (1), 311.

Harter, SP., Nisonger, T.E.\&Aiwei Weng (1993). Semantic relationships between cited and citing articles in library and Information science journals.,Journal of the American Society for Information Science, Vol. 44 (9), 543-552.

Kessler, M.M. (1986). Bibliographic coupling between scientific papers., American Documentation, No.14, 10-25.

(1965). Comparison of the results of bibliographic coupling and analyric subject indexing. American Documentation, No.16, 223-233.

McCain, K.W. (1986). Co-cited author mapping as valid representation of intellectual structure., Journal of the American Society for Information Science, Vol. 37 (3), 111-122.

(1989). Discriptor and citation retrival in the medical behavioral sciences literature: Retrival overlaps and novelty., Journal of the American Society for Information Science, Vol. 40 (2), 110114.

(1991). Core journal networks and co-citation maps: new bibliometric tools for serials research and managements., Library Quarterly, 66 (3), 311-336.

Small, H. (1973). Co-citation in the scientific literature: A new measure of the relationship between two documents., Journal of the American Society for Information Science, Vol. 24 (4), 265-269.

(1980). Co-citation context Analysis and the structure of Paradigms., Journal of Documentation Science, Vol. 36 (3), 183-196.

(1987). The Significance of Bibliographic References., Scientometric. 12, 339-341.

Vladutz, G. \& J. Cook (1984). Bibliobraphic coupling and subject relatedness., Proceeding ASIS $47^{\text {th }}$ Annual Meeting: 204-207. 